\title{
Using Audience Response Systems To Encourage Student Engagement And Reflection On Ethical Orientation And Behavior
}

Melinda J. Micheletto, Saint Michael's College, USA

\begin{abstract}
The purpose of this study was to use an audience response system (ARS) to engage students in classroom discussions concerning sensitive and controversial topics (e.g., business ethics), assess student's ethical orientation and conduct in unethical behaviors, and encourage reflection on their personal level of ethicality. Students used ARS devices to respond anonymously to questions regarding specific business-related ethical scenarios in a Principles of Marketing class. Students were asked six questions regarding their own conduct in certain behaviors and one question to evaluate their self-reported level of ethicality before the lecture/discussion and then again after the lecture/discussion. Nearly ninety-two percent of the students $(n=65)$ reported that they believed they were an ethical person at the beginning of the lecture/discussion and only seventythree percent of the students $(n=52)$ reported that they believed they were an ethical person at the end of the lecture/discussion. The study showed that an ARS can be used to engage students in classroom discussion that results in significant student reflection on the topic.
\end{abstract}

Keywords: Audience Response System; Student Engagement; Reflection; Business Ethics; Anonymity

\section{INTRODUCTION}

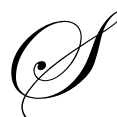

tudent engagement is a clear predictor of learning and learning tends to increase to the extent that students engage with classroom material (Kuh, 2003). Research has shown that students learn more effectively and retain information longer when they are actively engaged with issues and problems than they do when they passively listen to lectures (Bligh, 2000; Eble, 1983; McKeachie, 1967). Actively engaging students in learning activities that asks "what is the right thing to do," promotes learning on several levels (Sims, 2002). The difficulty lies in getting students to engage in deep and meaningful discussions and to divulge personal opinions regarding sensitive or controversial topics in a classroom setting.

Although traditional techniques can be used to assess opinions or behaviors, such as an informal "show of hands," paper-based polling, or holding cards with an answer/color, none of these techniques offer complete anonymity for the respondent. Assuring anonymity for student responses is crucial for authenticity, reliability, and success of the impending discussion, particularly if it is one of a sensitive, personal, or controversial nature. Anonymity also allows for neutrality and reassurance. Several studies recognized, through student self reporting, that students were more likely to participate if their answers were anonymous (Beekes, 2006; Bode, Drane, Kolikant, \& Schuller, 2009; Elliott, 2003).

An Audience Response System (ARS), a hand-held, technology-based device, allows instructors the opportunity to pose questions and students the option to actively participate by inputting answers and receiving immediate feedback about their individual responses. Additionally, the device allows students to observe how their responses compare to other members of the class. King and Robinson (2009) found that the use of an ARS increased the likelihood that students would participate and engage in class discussions. In particular, Robinson and Ritzko 
(2006) found that the use of an ARS increased the likelihood that students would partake in in-class opinion polls. Similarly, using an ARS to pose questions regarding an opinion on a complex social or ethical issue, promotes critical thinking ("Functions (or Uses) of Student Response Systems (SRS)," n.d.) and helps make learning personal.

Elliott (2003) indicates the value of an ARS in more controversial subjects remains to be explored and advocates using an ARS in the following manner: (1) initially ask students to select a multiple-choice answer most closely corresponding to their personal views, (2) discuss the topic, focusing on the range and reasons for the responses, and (3) ask the same, or a similar question, at the end of the discussion, to determine if student's views have changed as a result of the discussion. Salemi (2008) utilized this technique, asking opinion questions at the beginning of a lecture and subsequently asking the same question at the end of the lecture to determine if opinions changed over the course of the discussion.

This study employs Elliott's (2003) suggestion and builds on Salemi's (2008) use of opinion sampling and contributes to the literature by presenting one way in which an Audience Response Systems (ARS) can be utilized to engage students in discussion regarding ethical orientation and behaviors. These discussions can create "teachable moments" (Salemi 2008), promote interaction in the classroom, and encourage student reflection on their own ethical orientation and level of ethicality.

\section{LITERATURE REVIEW}

\section{Teaching Ethics}

Ethics are "well-founded standards of right and wrong that prescribe what humans ought to do" (Velasquez, Andre, Shanks, Meyer, \& Meyer, 1987); basically, they are a set of rules for behavior. A great deal of interest concerning the ethical perceptions of business students exists given the increase in the number of public disclosures of illegal activity in the business world (DeConinck \& Good, 1989; Knotts, Lopez, \& Mesak, 2000; Merritt, 2002; Zinkhan, Bisesi, \& Saxton, 1989). The matter of ethics was thought to be so significant that in 1976, the American Assembly of Collegiate Schools of Business (AACSB) called for the inclusion of ethics in the business curriculum (AACSB, 1987-88). Allan and Wood (2009) provide a syntheses on the body of literature that exists on the topic of ethics - how, when and where it should be taught.

The purpose of teaching ethics, however, is not to make people ethical, but to help people make better ethical decisions (Brown, 2000). It is this decision-making perspective that is necessary and is the underpinning for any pedagogical edict. Therefore, ethics should be an essential part of any business education, covering many of the functional business areas. For instance, to effectively teach marketing ethics, Hunt and Vitell (2005) suggest emphasizing students' consideration of ethical issues and ethical problems, exposure to normative theories or frameworks that help them make informed ethical decisions, and reflection on those decisions. Therefore, "teaching business ethics is a series of learning experiences that encourages active, experiential learning and uses a variety of learning activities" (Sims 2002, p. 82).

Ferrell, Fraedrich, and Ferrell (2000) suggest that students should be introduced to conversations about ethics early in their business education in order to assess their moral attitudes. Teaching ethics to business students should focus on making students aware of ethical issues in business and developing their sense of moral obligation (Wynd \& Mager, 1989). One of the goals that Gandz and Hayes (1998) recommended for teaching business ethics is to increase students' awareness of the ethical, legal, and social dimensions of business decision making. Similarly, Brinkmann and Sims (2001) proposed the following outcome as a result of classes that have ethics as a specific component: to "know thyself, your own moral values and thresholds" (p. 175). Hunt and Vitell (2005) weighed in adding that courses in ethics should attempt to encourage students to "acquire and refine the elements of a personal moral code that will, at the absolute minimum, keep one's self and one's coworkers out of prison" (p. 23).

In order to establish a baseline for a meaningful discussion regarding ethics and to assess ethical orientation and perception of ethicality, it is important to understand student's involvement in ethical/unethical behaviors. This can be a difficult task given the sensitive nature of the topic. A question may be deemed sensitive if it "raises concerns about disapproval or other consequences (such as legal sanctions) for reporting truthfully or it the question 
itself is seen as an invasion of privacy." (Tourangeau \& Smith, 1996, p. 276). Respondents may be reluctant to express or may be incapable of conveying their true feelings or beliefs on sensitive topics for ego-defensive or impression management reasons. The outcome is data that are biased toward respondents' perceptions of what is considered correct or socially acceptable (Maccoby \& Maccoby, 1954).

Persuading students to actively participate in classroom discussions is difficult in and of itself, but becomes even more difficult when the topic may be deemed sensitive, controversial, or personal. Pratton and Hales (1986) defined active participation as 'the result of a deliberate and conscious attempt on the part of a teacher to cause students to participate overtly in a lesson' (p. 211). Active participation, often measured by active student responses (e.g., hand raising), can be promoted by posing questions to students. Often times, however, students are reluctant to answer questions in front of the peers, thus questions may only be answered by the most knowledgeable or most daring. Another technique to enhance active participation is to use response cards - "cards or signs that are simultaneously held up by all students in a class to display an answer or other response to a question posed by the instructor" (Marmolejo, Wilder, \& Bradley, 2004, p. 405). Response cards certainly offer a method of participation; however, they do not offer total anonymity and therefore, may not reveal a student's true opinion or actual behavior for fear of retribution or embarrassment. An Audience Response System (ARS) can be used to gauge student opinion on controversial or sensitive issues, to encourage debate and discussion, and can turn a passive lecture into an interactive interexchange of ideas (EDUCAUSE Learning Initiative, 2005).

\section{Using an Audience Response System}

An Audience Response System (ARS) is a wireless response system that allows students to participate in presentations or lectures by submitting responses to interactive questions (e.g., multiple choice, true/false, yes/no, Likert scale) using a "clicker" or hand-held response pad to send information to a receiver. This device has been called many things, including "student," "personal," "classroom," "electronic," "group" or "audience" response systems and electronic voting systems, but are commonly referred to as "clickers" (see Kay, 2008 for a complete list). The computer instantaneously records individual responses and displays the response on a projection screen, usually in the form of a histogram or bar graph. Although some form of an ARS has been available since the 1960s (Judson and Sawada 2002), it has become more popular in higher education in the last decade as faculty explore pedagogical techniques to increase student interaction (Bode et al., 2009; Caldwell, 2007; EDUCAUSE Learning Initiative, 2005; Herreid, 2006).

Using an ARS has been found to improve classroom interaction (Hoekstra, 2008; Sanders, 2007; Zhu, 2007) encourage student engagement with course content (Bode et al., 2009; Robinson \& Ritzko, 2006), and promote a more learner-centered, active learning environment as compared to traditional, passive learning, lecturebased instruction (Caldwell, 2007; Crouch \& Mazur, 2001; Hoffman \& Goodwin, 2006).

By using an ARS, each student is given the opportunity to respond electronically (often times anonymously) to a variety of types of question(s) posed by the instructor (e.g., multiple choice, true/false, Likert scale). This method of instruction creates a more active classroom environment where every student can participate and play a role in the classroom discussion (Rodgers \& Starrett, n.d.). See Kay and LaSage (2009) for a more thorough literature review regarding the benefits of using an ARS.

Certainly, data and information from outside sources can be used to illustrate the prominence of and attitudes toward unethical behavior in the workplace; however, accessing the information from the students sitting in the classroom allows students to be active participants in the discussion. This active participation can increase interest in the topic, thus enhancing learning, comprehension, reflection, and retention of material. An ARS can engage students in discussions and collect student responses in a myriad of ways. An ARS can be used in situations where there are definitive answers to questions such as evaluating student learning after a lecture, assessing how well prepared students are for class, and pre- and post-test analysis. Additionally, an ARS can be used to inquire about student opinions, for instance, posing "ice breaker" questions to start class or collecting student opinions on current events. 
Mollborn and Hoekstra (2010) discuss several types of questions that can be used to "encourage students to solidify their knowledge to new empirical situations" (p. 21). Opinion questions can be used to solicit students' perceptions of ideas to initiate discussion in a way that encourages critical thinking of and reflection on course concepts and can be asked before starting a new topic, after a lecture, of both so as to discover whether student's opinions have changed (Mollborn \& Hoekstra, 2010). One advantage of asking opinion questions using an ARS is that the students are able to see the breakdown of opinions, beliefs, and values that exist among their fellow students. Therefore, the information generated by these types of questions can encourage students to consider the "social and cultural contexts that have shaped their beliefs" (Mollborn \& Hoekstra, 2010, p. 21). Lincoln (2008) encouraged using an ARS to ask questions on controversial topics and collect anonymous responses.

Regardless of the type of question being posed, an ARS can operate in two different modes, identified and anonymous. In identified mode, individual responses are directly tied to a specific response card and are useful for assessment-type questions. In anonymous mode, individual responses do not directly correspond to a specific response card and are useful for opinion-type questions. The anonymity that the technology provides offers an opportunity to encourage interaction and group learning (Williams, 2002). Williams (2002) advises that the "privacy of the choice means that, unlike in face-to-face groups, each individual can express the choice they incline to, rather than only a choice they feel able to explain and justify to others." Many students feel that the best feature of an ARS is the anonymity of their response (Beekes, 2006; Bode et al., 2009; Elliott, 2003) and "being able to answer a question anonymously without fear of having the wrong answer" (Morse, Ruggieri, \& Whelan-Berry, 2010, p. 105). According to the Turning Technologies website, "not all questions have to have a right answer" and thus, the anonymous feature on the ARS can be used to reveal more honest opinions and candid insights on specific topics ("Student Response Best Practices," n.d.).

\section{METHODOLOGY}

\section{Participants}

A total of seventy-one undergraduate students in three separate Introduction to Marketing courses at a small, liberal arts school in the Northeast took part in this study. The majority of the students (79\%) were college seniors, the remainder were college juniors (21\%). Women comprised 36 percent of the respondents. The Introduction to Marketing course is a required course for Business majors and 84.5 percent of the respondents were Business majors.

\section{Materials}

The TurningPoint ${ }^{\mathrm{TM}}$ audience response system by Turning Technologies (Turning Technologies, LLC, Youngstown, OH, USA) was used in this study. The TurningPoint ${ }^{\mathrm{TM}}$ audience response system consists of a set of ResponseCards $^{\circledR}$ (handheld devices with keypads), a USB transceiver, and software that integrates with Microsoft ${ }^{\circledR}$ PowerPoint ${ }^{\circledR}$. Additionally, a computer, with a USB connector for the ARS receiver, was used to capture the data and a projection screen was used to project the questions and a histogram of the responses. The TurningPoint ${ }^{\mathrm{TM}}$ software allowed for integration of the results with Microsoft Office ${ }^{\circledR}$ so the results could be automatically displayed within a PowerPoint ${ }^{\circledR}$ presentation and responses were tracked and recorded via Excel $^{\circledR}$. (http://www.turningtechnologies.com).

\section{Procedure}

The ARS was part of a pilot program in three lecture sections of Introduction to Marketing in the fall of 2009 (two classes) and spring of 2010 (one class). The ARS was used every class period, except exam days and presentation days. It was used in a variety of ways throughout the semester (e.g., chapter quizzes, voting on favorite ads, exam reviews, and opinion questions embedded in the lecture), therefore, the students were familiar and comfortable with the technology by the time the data for this study was collected.

Throughout the semester, each student was assigned a particular response card; however, on this day, to ensure complete anonymity for their answers, the students were instructed to pick any response card from a basket. 
Once seated, the instructor advised the students to switch keypads with a neighbor (or two). Lastly, the instructor demonstrated how the ARS was set to anonymous mode and explained that their answers could in no way be tracked back to them individually. It was emphasized that the responses were completely confidential, their name would not be associated with their answers, and the instructor would have no knowledge of a student's individual response.

Near the end of the semester, during a lecture on Business Ethics, six questions (see Table 1) were posed to three separate classes of students regarding somewhat questionable behaviors. The students were asked to respond to the questions based on their own engagement in the behavior. Additionally, students were asked whether they considered themselves to be an ethical person at the beginning of the lecture and again at the end of the lecture. All questions were formatted as dichotomous (Yes/No) questions. The answers were captured using the computer program TurningPoint ${ }^{\mathrm{TM}}$ (Turning Technologies, LLC, Youngstown, OH, USA).

Table 1: Ethical Questions Posed to Class

\begin{tabular}{|l|l|}
\hline 1. & As an employee, I have surfed the Internet shopping for personal items on company time \\
\hline 2. & Have you ever redeemed an expired coupon? \\
\hline 3. & Have you ever stolen anything? \\
\hline 4. & Have you ever downloaded a song/movie/video illegally? \\
\hline 5. & Have you ever returned a product you used? \\
\hline 6. & Have you ever taken credit for someone else's work? \\
\hline
\end{tabular}

\section{RESULTS}

All seventy-one students had access to an ARS response card and were informed and shown that the data collection method was set on "anonymous." It should be noted that students were given ample time to ponder and answer each question. In all but four cases, every student participated by submitting an answer to each question using the ARS response card. One question in particular ("have you ever stolen anything?"), did not yield answers from every student in every class (i.e., one student in each class failed to participate). This could be because of the inability to answer due to misinterpretation of the question (see Limitation section below) or lack of interest in answering the question. As nearly every student participated in all other questions, it is doubtful that a student would be concerned about answering this particular question.

At the beginning of the lecture on Business Ethics, the majority of students (91.5\%) responded affirmatively when asked if they believed they were an ethical person (see Table 2). Interspersed throughout the lecture were six questions inquiring about their individual conduct in specific behaviors (see Table 1). After each question was asked and answered, the results from each question were tallied and presented to the class. Discussion then ensued regarding how and why certain decisions were made and if applicable, which theories they might have subscribed to when making these decisions (e.g., teleology, deontology, situational ethics). Additionally, the legal ramifications and/or the impact on business/industry that these behaviors could have were discussed.

Table 2: Results - Self-reported Level of Ethicality

\begin{tabular}{|l|c|c|c|c|c|c|c|}
\hline & \multicolumn{2}{|c|}{$\begin{array}{c}\text { Fall 2009 (230) } \\
\mathbf{n = 2 6}\end{array}$} & \multicolumn{2}{c|}{$\begin{array}{c}\text { Fall 2009 (1000) } \\
\mathbf{n = 2 6}\end{array}$} & \multicolumn{2}{c|}{$\begin{array}{c}\text { Spring 2010 } \\
\mathbf{n = 1 9}\end{array}$} & \multicolumn{2}{c|}{$\begin{array}{c}\text { Overall } \\
\text { Questions: }\end{array}$} & Yes & No & Yes & No & Yes & No & Yes \\
\hline Ethical Person (before) & $96.15 \%$ & $3.85 \%$ & $88.5 \%$ & $11.5 \%$ & $89.5 \%$ & $10.5 \%$ & $91.5 \%$ \\
\hline Ethical Person (after) & $73.1 \%$ & $26.9 \%$ & $73.1 \%$ & $26.9 \%$ & $73.7 \%$ & $26.3 \%$ & $73.2 \%$ \\
\hline
\end{tabular}

Engagement in what might be considered unethical or questionable behaviors was present in all classes, ranging from $50.0 \%$ to $95.7 \%$, however, some classes reported more unethical behavior than others (see Table 3 ). Overall, the behavior that was reported as being engaged in the most was participating in the illegal download of songs, movies, or videos (95.7\%) and the behavior that was reported as being engaged in the least was taking credit for someone else's work (39.4\%). It should be noted, however, that separate classes had different results. For example, the question regarding taking credit for someone else's work yielded a $54.2 \%$ positive response in one 
class, yet a $16.7 \%$ positive response in another. This discrepancy could be due to the fact that one class is incredibly more ethical or perhaps more realistically, that the students may have misinterpreted the question (see Limitations section below).

Table 3: Results - Self-reported Behavior

\begin{tabular}{|l|c|c|c|c|c|c|c|}
\hline & \multicolumn{2}{|c|}{$\begin{array}{c}\text { Fall 2009 } \\
\text { n=26 }\end{array}$} & \multicolumn{2}{c|}{$\begin{array}{c}\text { Fall 2009 } \\
\text { n=26 }\end{array}$} & \multicolumn{2}{c|}{$\begin{array}{c}\text { Spring 2010 } \\
\text { n=19 }\end{array}$} & Overall \\
\hline Questions: & Yes & No & Yes & No & Yes & No & Yes \\
\hline Surfed Internet on company time & $61.5 \%$ & $38.5 \%$ & $57.6 \%$ & $42.3 \%$ & $47.4 \%$ & $52.6 \%$ & $56.4 \%$ \\
\hline Redeemed expired coupon & $56 \%$ & $44 \%$ & $53.9 \%$ & $46.1 \%$ & $36.8 \%$ & $63.2 \%$ & $50.0 \%$ \\
\hline Stolen anything & $91.7 \%$ & $8.3 \%$ & $80 \%$ & $20 \%$ & $76.5 \%$ & $23.5 \%$ & $83.3 \%$ \\
\hline Made illegal download & $96 \%$ & $4 \%$ & $100 \%$ & $0 \%$ & $88.9 \%$ & $11.1 \%$ & $95.7 \%$ \\
\hline Returned used product & $60 \%$ & $40 \%$ & $53.9 \%$ & $46.1 \%$ & $31.6 \%$ & $68.4 \%$ & $50.0 \%$ \\
\hline Taken credit for someone else's work & $54.2 \%$ & $45.8 \%$ & $41.7 \%$ & $58.3 \%$ & $16.7 \%$ & $83.3 \%$ & $39.4 \%$ \\
\hline
\end{tabular}

Most interesting are the data from the question posed at the end of the lecture. Students were asked once again, whether they believed they were an ethical person. Although the majority of the students (73.2\%) still believed they were an ethical person, compared to $91.5 \%$ at the beginning of the lecture, overall, their assessment regarding their personal level of ethicality changed dramatically.

\section{DISCUSSION}

This study evaluated the use of an ARS in discussions concerning a sensitive or controversial topic (e.g., self-reported ethical behavior) with the anticipation that this would promote active-learning, student engagement, and student reflection. Students were given an opportunity to (1) anonymously answer questions regarding their own ethical/unethical behavior and perceived level of ethicality, (2) discuss the nature and ramifications of unethical behavior, and (3) reflect upon their own ethicality. Overall, student's reflection upon their level of ethicality changed dramatically after preliminarily measuring their personal perception of ethicality and discussing ethical/unethical behaviors/scenarios.

Utilizing the anonymous feature of the ARS facilitated rapid and confidential collection of sensitive data regarding self-reported behaviors and perceived ethicality. If students had not been assured of complete anonymity, they might not have been compelled to answer honestly. Obtaining candid answers to the questions allowed for an open forum of discussion about unethical behavior, the philosophy of ethics, and the consequences, both professionally and personally, of unethical decision making. It also brings into question whether the level of refection would occur if the students felt their responses were being monitored. If indeed, as instructors, we are striving to find ways to engage our students in the learning process, create a more active- rather than passivelearning environment, and persuade students to reflect upon their actions and experiences, an ARS can be a tool that helps increase the chance of this happening.

\section{LIMITATIONS AND DIRECTIONS FOR FUTURE RESEARCH}

A key limitation of the study is sample size $(n=71)$. The study was focused on three small classes $(n=26$, $\mathrm{n}=26$, and $\mathrm{n}=19$, respectively). Data from additional courses, including non-business courses, would provide a more detailed perspective on how the ARS can be used to discuss and reflect upon sensitive and controversial topics. As many fields of work are confronted with ethical decision-making opportunities, an ARS could be utilized as a tool in countless courses to engage students in discussion, inquire about personal conduct, and encourage student reflection on level of ethicality.

Another limitation of the study could be that students were left to define and interpret the meaning of the questions (e.g., "stolen anything," "taken credit for someone else's work"). This was done purposefully to get a view of the student's general conduct with regard to unethical behavior and with the hope that the question would not bias their thoughts. However, the generic nature of the questions could have allowed for slight misinterpretations. For 
instance, Question \#3: "have you ever stolen anything" could be construed as "at any time in my life or in the last year or the last month?" Or, does "anything" truly mean "anything" (i.e., a pencil from a friend, a fork from the college dining hall, a car?). Additionally, Question \#6: "have you even taken credit for someone else's work?" could be understood as plagiarizing written work or taking a co-workers idea and presenting it as your own. Future questions could be more specific and thus might yield more specific and different results.

The anonymous feature of the ARS permits students to answer honestly and with confidence, knowing their individual answers are not being tracked. This allows the instructor to guide the discussion based on the results. Another way to assess student's opinions and perspectives of ethical behavior is to use a feature on TurningTechnologies ARS, "moment-to-moment" polling. By using this setting, students can rate something, or express their opinion on something on a scale of -2 to +2 at regular intervals, again anonymously. This could allow an instructor to observe when and how student's opinions are changing as the discussion progresses over the class period and could lead to an even more profound discussion. In the end, students are encouraged evaluate their own opinions and perspectives and reflect upon their own actions with regard to ethical behaviors.

\section{CONCLUSION/IMPLICATIONS}

This study used an audience response system (ARS) to engage students in classroom discussions concerning business ethics, assess their ethical orientation and conduct in unethical behaviors, and encourage reflection on their personal level of ethicality. It was shown that an ARS can be used to successfully engage students in classroom discussion that results in significant student reflection on the topic.

Although this study focused on using an ARS to teach business ethics, it could certainly be used to enhance discussion of and reflection on sensitive or controversial topics in a variety of fields, from political science, to health education, to psychology, to bio-medical ethics, just to name a few. It is the anonymous feature of the ARS that enables the instructor to facilitate the impending discussion by posing important, perhaps controversial questions and ensuring truthful and candid answers from students.

\section{AUTHOR INFORMATION}

Melinda Micheletto is currently an Associate Professor at Saint Michael's College in Colchester, Vermont. She earned her Ph.D. from the University of Tennessee. As an educator, Melinda utilizes different teaching techniques to motivate her students and assist them in the learning process and is actively engaged in classroom activities that utilize innovative pedagogical tools. Melinda has become increasingly technologically driven in the classroom, collaborating with Instructional Technology to promote the use of several technologically-based pedagogies. She also employs hand-on, active learning activities and has recruited nearly 30 local, small, or not-for-profit organizations for student-based projects. E-mail: mmicheletto@smcvt.edu

\section{REFERENCES}

1. AACSB (1987-88). AACSB: Accreditation Council Policies and Standards. American Assembly of Collegiate Schools of Business, Saint Louis, MO.

2. Allen, D. \& Wood, N. T. (2009). Incorporating ethics into the marketing communications class: The case of old Joe and new Jo Camel. Marketing Education Review, 19(2), 63-71.

3. Beekes, W. (2006). The "millionaire" method for encouraging participation. Active Learning in Higher Education, The Journal of the Institute for Learning and Teaching, 7(1), 25-36.

4. $\quad$ Bligh, D. A. (2000). What's the Use of Lectures? San Francisco, CA: Jossey-Bass.

5. Bode, M., Drane, D., Kolikant, Y., \& Schuller, M. (2009). A clicker approach to teaching calculus. Notices of the American Mathematical Society, 56(2), 253-256.

6. Brinkmann, J. \& Sims, R. R. (2001). Stakeholder-sensitive business ethics teaching. Teaching Business Ethics, 5(2), 171-193.

7. Brown, M. T. (2000). Working ethics: Strategies for decision making and organizational responsibility. Regent Press, vii. 
8. Caldwell, J. (2007). Clickers in the large classroom: Current research and best-practice tips. CBE-Life Sciences Education, 6, 9-20.

9. Crouch, C. H. \& Mazur, E. (2001). Peer instruction: Ten years of experience and results. American Journal of Physics, 69, 970-977.

10. DeConinck, J. B. \& Good, D. J. (1989). Perceptual differences of sales practioners and students concerning ethical behavior. Journal of Business Ethics, 8(9), 667-676.

11. Eble, K. (1983). The aims of college teaching. San Francisco, CA: Jossey-Bass.

12. EDUCAUSE Learning Initiative. (2005). 7 things you should know about clickers. Retrieved from http://net.educause.edu/ir/library/pdf/ELI7002.pdf

13. Elliott, C. (2003). Using a personal response system in economics teaching. International Review of Economics Education, 1(1), 80-86.

14. Ferrell, O. C., Fraedrich, J., \& Ferrell, L. (2000). Business ethics: Ethical decision making and cases $\left(4^{\text {th }}\right.$ ed.). Boston, MA: Houghton Mifflin.

15. Functions (or Uses) of Student Response Systems (SRS). University of Wisconsin-Milwaukee's Student Response Systems (SRS) Website. Retrieved from http://www.uwm.edu/Dept/LTC/SRS/students.html

16. Gandz, J. \& Hayes, N. (1988). Teaching Business Ethics. Journal of Business Ethics, 7(9), 657-669.

17. Herreid,C. F. (2006). Clicker cases: Introducing case study teaching into large classrooms. Journal of College Science Teaching, 26(2), 43-47.

18. Hoekstra, A. (2008). Vibrant student voices: Exploring effects of the use of clickers in large college courses. Learning, Media, and Technology, 33(4), 329-41.

19. Hoffman, C. \& Goodwin, S. (2006). A clicker for your thoughts: Technology for active learning. New Library World, 107(1228/1229), 422-433.

20. Hunt, S. D. \& Vitell, S. (2005). Personal moral codes and the Hunt-Vitell theory of ethics. In R. A. Peterson \& O. C. Ferrell (Eds.). Business Ethics: New Challenges for Business Schools and Corporate Leaders (pp. 18-37). Armonk, NY: M. E. Sharpe.

21. Judson, E. \& Sawada, D. (2002). Learning from the past and present: Electronic response systems in college lecture halls. Journal of Computers in Mathematics and Science Teaching, 21, 167-181.

22. Kay, R. H. (2008). Appendix A - Labels Used to Describe Audience Response Systems. Retrieved from http://faculty.uoit.ca/kay/papers/arsrev/AppendixA_Labels.pdf

23. Kay, R. H. \& LaSage, A. (2009). Examining the benefits and challenges of using audience response systems: A review of the literature. Computers \& Education, 53, 819-829.

24. King, S. O. \& Robinson, C. L. (2009). 'Pretty lights' and maths! Increasing student engagement and enhancing learning through the use of electronic voting systems. Computers \& Education, 53, 189-199.

25. Knotts, T. L., Lopez, T. B., \& Mesak, H. I. (2000). Ethical judgments of college students: An empirical analysis. Journal of Education for Business, 75(3), 158-163.

26. Kuh, G. D. (2003). What we're learning about student engagement from NSSE. Change, 35, $24-32$.

27. Lincoln, D. J. (2008). Teaching with clickers in the large-size principles of marketing class. Marketing Education Review, 18(1), 39-45.

28. Maccoby, E. E. \& Maccoby, N. (1954). The interview: A tool of social science. In G. Lindzey (Ed.), Handbook of Social Psychology. (Vol. 1, pp. 449-487). Cambridge, MA: Addison-Wesley.

29. Marmolejo, E. K., Wilder, D. A., \& Bradley, L. (2004). A preliminary analysis of the effects of response cards on student performance and participation in an upper division university course. Journal of Applied Behavior Analysis, 37(3), 405-410.

30. McKeachie, W. J. (1967). Research in teaching: The gap between theory and practice. In C. Lee (Ed.), Improving College Teaching. (pp. 211-239). Washington, D.C.: American Council on Education.

31. Merritt, J. (2002, September 16). For MBAs, soul-searching 101: Now, B-schools are emphasizing ethics and responsibility. Business Week, 64-65.

32. Mollborn, S. \& Hoekstra, A. (2010). 'A meeting of the minds': Using clickers for critical thinking and discussion in large sociology classes. Teaching Sociology, 38(1), 18-27.

33. Morse, J., Ruggieri, M., \& Whelan-Berry, K. (2010). Clicking our way to class discussion. American Journal of Business Education, 3(3), 99-108.

34. Pratton, J. \& Hales,L. W. (1986). The effects of active student participation on student learning. Journal of Educational Research, 79(4), 210-215. 
35. Robinson, S. \& Ritzko, J. (2006). Increasing student engagement through electronic response devices. Proceedings of the Academy for Educational Leadership, 11(1), 79-82.

36. Rodgers, M. L. \& Starrett, D. A. Calling All Students...Come in. Students..., UC Riverside http://www.cnc.ucr.edu/clickers/index.php?content=artilces/calling all students.html

37. Salemi, M. K. (2008). Clickenomics: Using a classroom response system to increase student engagement in a large-enrollment principles of economics course. Retrieved from http://www.unc.edu/ salemi/Papers/Clickenomics\%20JEE\%20Revision\%206_2008.pdf

38. Sanders, J. J. (2007). Clicker pedagogy case study. School of Business, University of Southern Maine. Retrieved from http://.iclicker.com/dnn/LinkClick.aspx?ñleticket=sMovwqz\%2FKbQ\%3D\&tabid=168

39. Sims, R. R. (2002). Teaching business ethics for effective learning, Westport, CT: Quorum Books.

40. Student response best practices. Retrieved from http://www.turningtechnologies.com/studentresponsesystems/researchcasestudies/bestpractices/

41. Tourangeau, R. \& Smith, T. W. (1996). Asking sensitive questions: The impact of data collection mode, question format, and question context. Public Opinion Quarterly, 60, 275-304.

42. Velasquez, M., Andre, C., Shanks, T., Meyer, S. J., \& Meyer, M. J. (1987). What is ethics? Issues in Ethics IIE, l(1). Retrieved from http://www.scu.edu/ethics/practicing/decision/whatisethics.html.

43. Williams, D. (2002, May 21). As seen on TV: 'Who wants to be a millionaire' technology is helping lecturers find out whether they are making themselves understood. The Guardian. Retrieved from http://www.guardian.co.uk/education/2002/may/21/highereducation.careers 1

44. Wynd, W. R. \& Mager, J. (1989). The business and society course: does it change student attitudes? Journal of Business Ethics, 8(6), 487-491.

45. Zhu, E. (2007). Teaching with clickers. Center for research on learning and teaching occasional papers. 22. Retrieved from http://www.crlt.umich.edu/publinks/CRLT_no22.pdf.

46. Zinkhan, G. M, Bisesi, M, \& Saxton, M. J. (1989). MBA's changing attitudes toward marketing dilemmas: 1981-1987. Journal of Business Ethics, 8(12), 963-974. 


\section{$\underline{\text { NOTES }}$}

